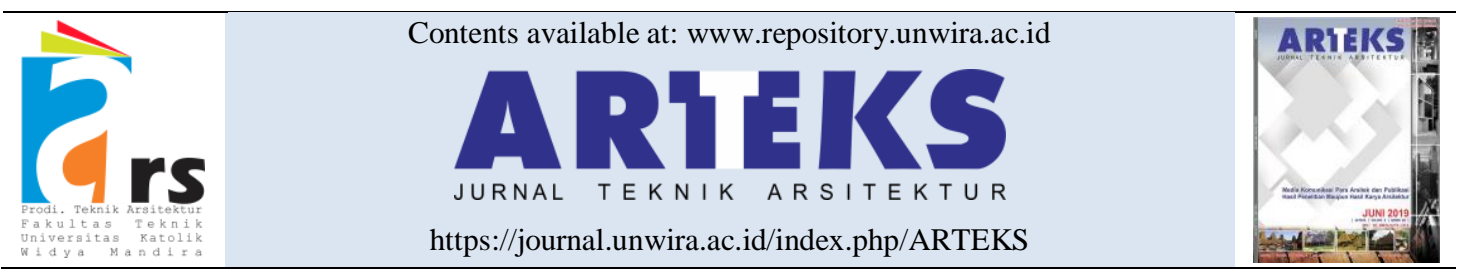

Research paper

doi: http://doi.org/10.30822/arteks.v4i1.78

\title{
Karakteristik fasad bangunan Indis di kawasan Jalan Prawitotaman Yogyakarta
}

\section{Dessy Anggraini, Dwita Hadi Rahmi*}

Jurusan Teknik Arsitektur dan Perencanaan, Fakultas Teknik, Universitas Gadjah Mada Jl. Grafika, No. 2, Senolowo, Sinduadi, Mlati, Kabupaten Sleman, Yogyakarta, Indonesia

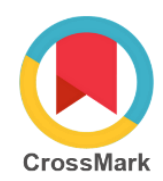

\begin{tabular}{l}
\hline ARTICLE INFO \\
\hline Article history: \\
Received May 12, 2019 \\
Received in revised form May 25, 2019 \\
Accepted September 20, 2019 \\
Available online December 16, 2019
\end{tabular}

Keywords:
Characteristics buildings
Facade
Indich buildings

*Corresponding author: Dwita Hadi Rahmi Jurusan Teknik Arsitektur dan Perencanaan, Fakultas Teknik, Universitas Gadjah Mada,

Yogyakarta, Indonesia

Email: dwitahr@ugm.ac.id

\section{ABSTRACT \\ Façade characteristics of Indich buildings in Jalan Prawirotaman Yogyakarta}

Prawirotaman, Yogyakarta has a unique characteristic with the facade of Indich buildings which used to be the house for Kraton warriors and continued to grow, so that many new buildings emerged with a modern style that could eliminate identity and characteristics in the Jalan Prawirotaman area. Therefore, we need a comprehension of the façade characteristics for Indich buildings so that it can be used as an idea in the design of buildings in the future. This study uses the rationalistic paradigm with qualitative deductive methods. The results of the study show types in each element and the most dominant types including limasan roof with the addition of a small roof (due to the addition of the front room) with clay tile, concrete material walls with cream or white color, the door uses 2 door leaves wood material combination glass rayban, glass massif window, elevation of the floor between $20-60 \mathrm{~cm}$ (requires stairs for access) and dominated by one-story buildings. Facade pattern of the entire Indich buildings in the Jalan Prawirotaman area has an asymmetrical pattern but seems balanced and ornaments in the building are in the ventilation, while the column with firm lines and concrete material elements shows the different characteristics variables from the characteristics Indich building basic theory. Examples of the different elements are the windows and building patterns because of the current development and changed by building owners.

\section{Pendahuluan}

Kota Yogyakarta dalam perkembangannya merupakan salah satu kota yang menjadi tempat aktivitas pemerintah Belanda dalam masa pemerintahannya dan menjadi kota tua yang memiliki banyak sejarah (DIY 2014). Pada jaman penjajahan Belanda, kebudayaan Barat mulai masuk dan mempengaruhi Kota Yogyakarta. Dibuktikan oleh banyaknya bangunan Indis seperti rumah, sekolah, kantor dan benteng pertahanan (Mahatmanto 2015). Bangunan Indis merupakan fenomena unik dalam perkembangan arsitektur di Indonesia (Sumalyo 1993; Mahatmanto 2015). Dikatakan unik karena bangunan Indis yang tersebar di Indonesia memiliki ciri yang berbeda-beda akibat terjadinya penggabungan gaya arsitektur antara budaya penjajah dengan budaya Bangsa Indonesia (Makkasahe 2018). Penggabungan tersebut memunculkan kepekaan bangunan Indis terhadap iklim serta lingkungan tropis, terlihat dari elemenelemen konstruksinya untuk mengatur penghawaan dan pencahayaan serta perlindungan 
terhadap hujan. Bangunan dengan plafon tinggi juga merupakan cara untuk menghindari panas dalam ruangan (Sumalyo 1993; Mahatmanto 2015). Bila dilihat dari peninggalan budaya yang ada, latar belakang bangunan Indis yang ada di Yogyakarta berawal dari pejalanan sejarah Kraton dan bangsa-bangsa yang pernah menguasai Kota Yogyakarta (Wibisono and Ronald 2014).

Salah satu contoh jejak sejarah Kraton dan penjajah Belanda yang juga dijadikan objek dalam penelitian ini adalah Jalan Prawirotaman. Zaman dulu Jalan Prawirotaman merupakan daerah permukiman prajurit Kraton yang didominasi oleh bangunan rumah tinggal bergaya Indis (Kristiani and Dharoko 1996), terlihat pada rumah Indis di Jalan Prawirotaman memiliki ukuran yang besar dengan jarak lantai ke plafon 3,5 sampai dengan 4 meter, atap yang tinggi, memiliki beranda depan, teritisan yang lebar, pintu berada di tengah bangunan dan diapit dengan dua jendela besar. Wardani (2011) menambahkan bahwa ciri-ciri desain bangunan Indis yang popular adalah fasad simetris, material menggunakan batu bata dan kayu, pintu bangunan menggunakan dua daun pintu dan jendela besar berbingkai kayu (Laksmi Kusuma Wardani and Leona Triyulianti 2011).

Jalan Prawirotaman terletak di lokasi yang strategis dekat dengan tempat wisata terkenal lainnya dan cenderung berkembang menjadi area komersial. Saat ini bangunan-bangunan yang ada di Jalan Prawirotaman didominasi dengan bangunan-bangunan bergaya modern. Sebagai daerah bersejarah seharusnya Jalan Prawirotaman memiliki peran yang sangat penting sehingga harus dijaga karakteristik kawasannya yang memiliki nilai historis.

Elemen pada bangunan yang paling mudah terlihat oleh para wisatawan dan menjadi karakter suatu kawasan adalah elemen fasad bangunannya (Salura 2013). Untuk menjaga identitas dan karakteristik pada Jalan Prawirotaman diperlukan pemahaman terhadap karakteristik fasad bangunan Indisnya. Penelitian ini bertujuan untuk menemukan karakteristik fasad bangunan Indis di kawasan Jalan Prawirotaman saat ini. Penelitian ini menggunakan teori fasad sebagai teori yang mendasari terbentuknya karakteristik fasad bangunan Indis yang ada di kawasan Jalan Prawirotaman. Karakteristik fasad bangunan ini diperoleh dengan mempelajari, menghayati dan menganalisis objek dari segi fisik bangunan khususnya aspek bentuk. Penelitian-penelitan dengan objek elemen fasad menurut beberapa peneliti adalah atap (Karisztia, Pangarsa, dan Antariksa 2008), ornamen (Tri Widyanti, Antariksa, dan Yunita Titisari 2009; Askari dan Dola 2009; Fauziah, Antariksa, dan Ernawati 2012), material (Askari dan Dola 2009; Fauziah, Antariksa, dan Ernawati 2012, Ramli 2018)), dan tekstur (Askari dan Dola 2009; Fauziah, Antariksa, dan Ernawati 2012), dan kanopi (Santoso 2017).

\section{Metode penelitian}

Penelitian ini memakai paradigma rasionalistik dengan metode deduktif kualitatif. Dalam penelitian ini paradigma rasionalistik menggunakan kemampuan berpikir dan akal budi dalam memberikan makna empiri yaitu empiri logik dan empiri etik (Muhadjir 1996). Sugini (1997) mengatakan bahwa dalam metode penelitian rasionalistik, peneliti menggunakan ilmu sebagai penyederhana idealisasi dari realitas yang koheren dengan sistem logikanya, serta kebenaran tergantung pada pemikiran akal budi. Kebenaran akan berkaitan dengan konteks logika dan konteks etika (dari pandangan pengamat) (Sugini and Sudaryono 1997).

Penelitian ini berlokasi di Daerah Istimewa Yogyakarta yaitu tepatnya di Jalan Prawirotaman yang terletak 5-kilometer dari Kota Yogyakarta.

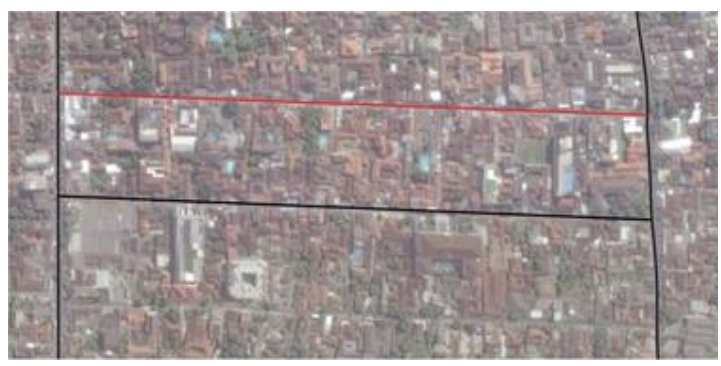

Gambar 1. Peta lokasi penelitian

Berdasarkan peta kawasan yang dilihat dari google earth, terlihat bahwa kawasan Jalan Prawirotaman terletak di daerah yang telah ramai dengan bangunan-bangunan. Kawasan ini terus berkembang pada bagian akomodasi wisata karena letaknya yang sangat strategis dekat dengan pusat kota dan tempat wisata lainnya. Lokasi kawasan yang diteliti adalah jalan yang diberi notasi berwarna merah yaitu Jalan Prawirotaman.

Kawasan Jalan prawirotaman merupakan jalan yang memiliki tingkat keramaian paling 
dominan dibandingkan jalan lainnya, Jalan Prawirotaman ini merupakan jalan pertama di kawasan Prawirotaman yang saat ini terus berkembang dengan bangunan-bangunan komersial.

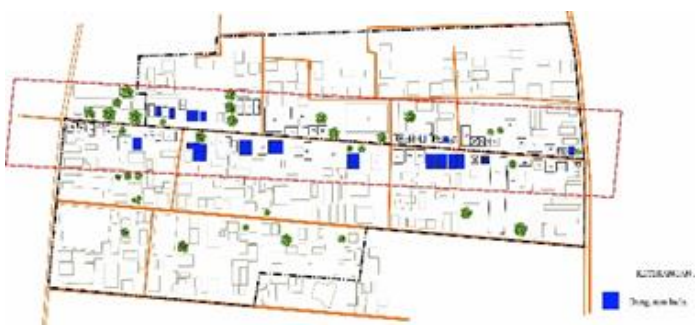

Gambar 2. Peta penyebaran bangunan Indis

Kriteria bangunan yang akan di jadikan objek peneitian adalah sebagai berikut:

1. Bangunan berukuran besar;

2. Fasad simetris;

3. Material menggunakan batu bata dan kayu;

4. Pintu menggunakan dua daun pintu;

5. Jendela besar berbingkai kayu;

6. Ornamen pada gavel;

7. Ornamen berbentuk persegi panjang, lingkaran atau segitiga yang disusun rapi, serta mengandung garis vertikal dan horizontal.

Fasad objek terpilih direkam secara visual dan digambar ulang kemudian diidentifikasi elemen pembentuk fasadnya. Pada kawasan Jalan Prawirotaman terdapat 14 bangunan Indis yang diteliti. Penampakan dari karakteristik fasad bangunan Indis yang ada di kawasan Jalan
Prawirotaman adalah hasil interaksi dialektis antara wujud fisik fasad bangunan dengan pengamat dan diambil yang paling dominan dari setiap elemen bangunan, hasilnya menjadi karakter bangunan Indis di kawasan Jalan Prawirotaman. Arinto (2018) juga mengatakan bahwa metode grafis atas artefak adalah salah satu metode untuk mengeksplorasi karakter dasar dari objek penelitian (Arinto 2018). Rapoport (1969) mengatakan bahwa kebenaran data adalah hasil interaksi dari nilai logik, nilai etik serta nilai emik dari subjek yang diteliti dan peneliti (Rapoport 1969).

\section{Temuan dan pembahasan}

Kawasan Jalan Prawirotaman merupakan jalan yang paling ramai dengan pengunjung. Keseluruhan deretan bangunan memiliki beragam fungsi, antara lain: sekolah, kios atau toko, restoran, hotel, rumah dan café. Bangunan Indis di kawasan Jalan Prawirotaman rata-rata mengalami perubahan fungsi dari sejak bangunan pertama kali didirikan sebagai permukiman prajurit Kraton. Pada saat terjadi perubahan fungsi dan seiring dengan berjalannya waktu, bangunan bangunan Indis yang ada di kawasan Jalan Prawirotaman melakukan renovasi sebagian atau keseluruhan. Berdasarkan kondisi saat ini, maka fasad bangunan Indis di kawasan Jalan Prawirotaman ini menjadi sangat beragam.

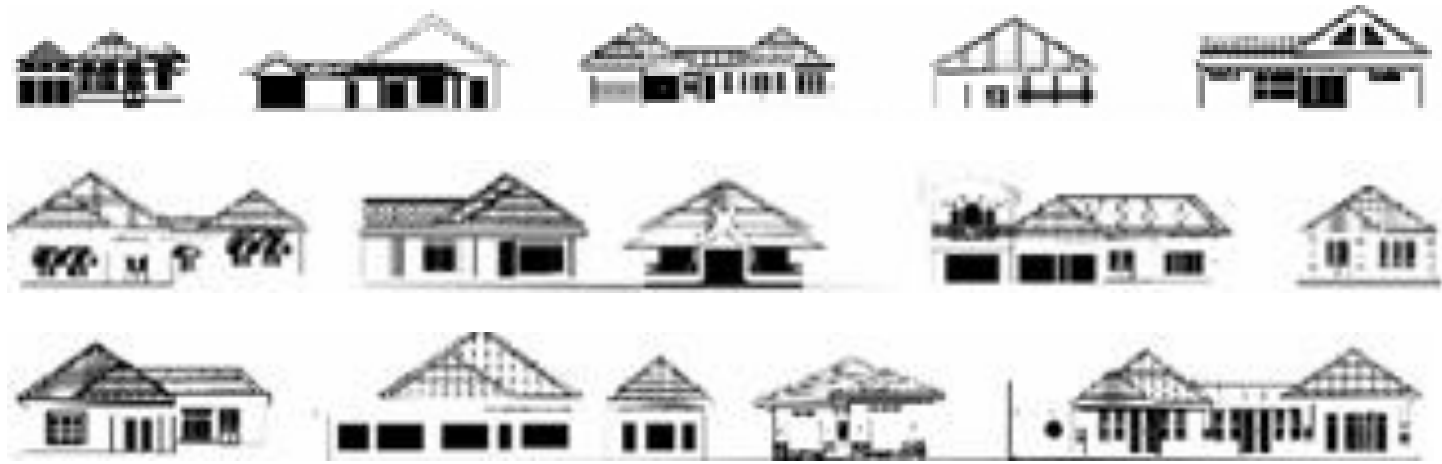

Gambar 3. Fasad bangunan Indis di kawasan Jalan Prawirotaman

Jumlah bangunan Indis yang ada di kawasan jalan Prawirotaman ini sebanyak 14 bangunan. Elemen fasad yang diteliti adalah atap, dinding, bukaan bangunan, lantai, pola dan ornamen.

\section{Bangunan Indis di kawasan Jalan Prawirotaman}

14 bangunan Indis yang diteliti adalah sebagai berikut: 


\section{Hotel Borobudur}

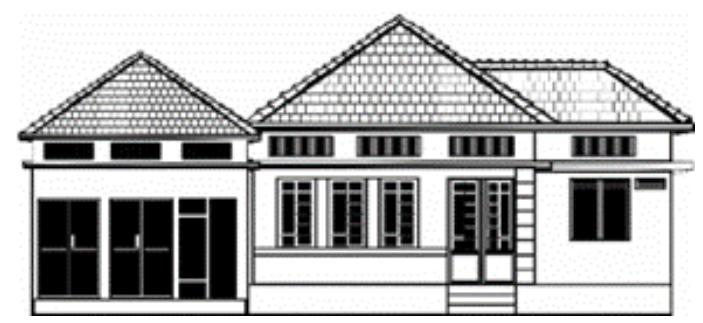

Gambar 4. Fasad bangunan hotel Borobudur

Bangunan ini terletak di Jalan Prawirotaman no. 5 Kelurahan Brontokusuman, Kecamatan Mergangsan, Kota Yogyakarta. Bangunan besar yang menggambarkan bangunan Indis yang sangat kokoh, menggunakan banyak bukaan untuk penghawaan di dalam ruangan. Pintu masuk menggunakan dua daun pintu dan terdapat peninggian lantai setingi $45 \mathrm{~cm}$ sehingga memerlukan tangga untuk akses masuk bangunan, pola bangunan asimetris sedangkan ornamen terdapat pada ventilasi bangunan yang unik. Saat ini bangunan ini berfungsi sebagai hotel dengan 6 kamar.

\section{Tropis home stay}

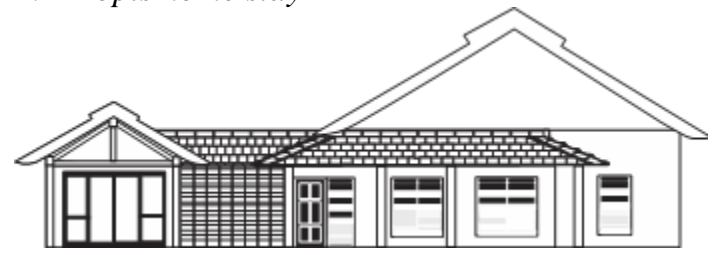

Gambar 5. Fasad bangunan Tropis home stay

Bangunan ini terletak di Jalan Prawirotaman no. 5A Kelurahan Brontokusuman, Kecamatan Mergangsan, Kota Yogyakarta. Bangunan Indis ini memiliki atap yang berbeda yaitu atap pelana yang sangat tinggi sehingga bangunan terlihat menonjol, menggunakan pintu dengan satu daun pintu material kayu, terdapat peninggian lantai setingi $20 \mathrm{~cm}$ dari permukaan tanah, pola bangunan simetris sedangkan ornamen terdapat pada ventilasi dengan material kayu dan penyusunan batu bata ekspos pada dindingnya.

\section{Annas store}

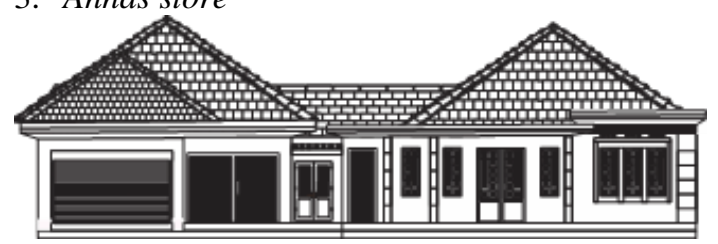

Gambar 6. Fasad bangunan Annas store
Bangunan ini terletak di Jalan Prawirotaman no. 7. Bangunan ini telah di renovasi untuk berbagai macam jenis usaha di dalamnya sehingga terdapat percampuran karakteristik khususnya pada pintu dan jendela. Ada 3 macam pintu pada bangunan ini yaitu rolling door, pintu kaca dan pintu kayu kombinasi kaca ray-ban dengan dua daun pintu. Sedangkan pada jendela menggunakan jendela kaca massif dan jendela kotak terpisah. Pola bangunan simetris.

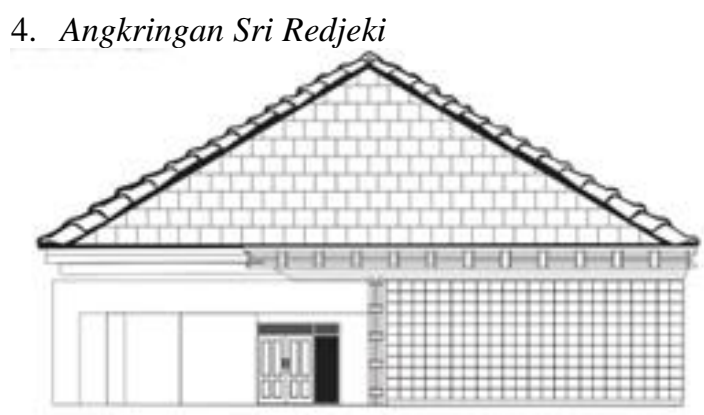

Gambar 7. Fasad bangunan Angkringan Sri Redjeki

Bangunan ini terletak di Jalan Prawirotaman no. 33 Kelurahan Brontokusuman, Kecamatan Mergangsan, Kota Yogyakarta. Bangunan Indis ini berfungsi sebagai rumah namun pada bagian depan digunakan sebagai angkringan, karakteristiknya terihat dari atapnya yang tinggi, bentuk bangunan yang simetris dan menggunakan dua daun pintu dengan material kayu.

\section{Tlahab Java coffee}

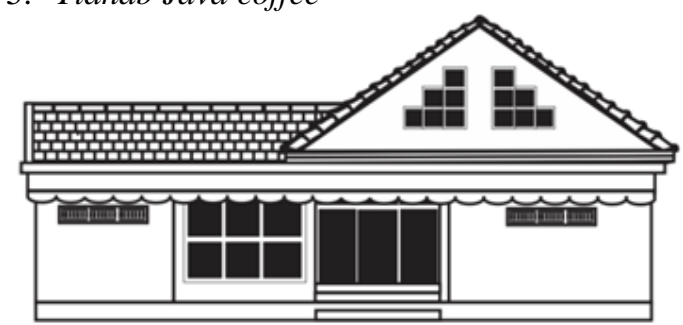

Gambar 8. Fasad bangunan Tlahab Java coffee

Bangunan ini terletak di Jalan Prawirotaman no. 80C Kelurahan Brontokusuman, Kecamatan Mergangsan, Kota Yogyakarta. Bangunan Indis ini telah banyak di renovasi dan digunakan sebagai caffe. Menggunakan atap pelana denagan ornamen glass box berbentuk segitiga, menggunakan pintu kaca dan jendela kaca massif, serta terdapat peningian lantai $60 \mathrm{~cm}$ dari permukaan tanah sehingga memerlukan tangga untuk akses ke bangunan. 


\section{Tilamas}

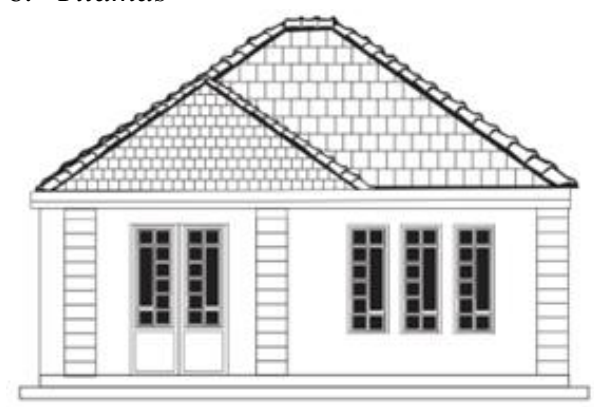

Gambar 9. Fasad bangunan Tilamas

Bangunan ini terletak di Jalan Prawirotaman no. 36 Kelurahan Brontokusuman, Kecamatan Mergangsan, Kota Yogyakarta. Bangunan Indis ini berfungs sebagai hotel dengan dinding beton berwarna putih, atap limasan dengan tambahan atap kecil di bagian depan bangunan, memiliki ornamen garis horizontal yan disusun vertikal pada bagian kolomnya, terdapat peninggian lantai $20 \mathrm{~cm}$ dan pola bangunan yang simetris.

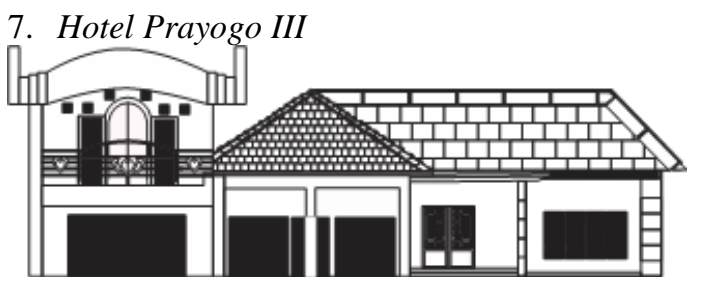

Gambar 10. Fasad bangunan hotel Prayogo III

Bangunan ini terletak di Jalan Prawirotaman no. 34 Kelurahan Brontokusuman, Kecamatan Mergangsan, Kota Yogyakarta. Bangunan indis ini sudah mengalami renovasi sehingga terlihat perbedaan yang signifikan pada fasadnya. Atap campuran sisi kanan bangunan menggunakan atap limasan dengan tambahan atap kecil dan sisi kiri bangunan menggunakan gable pada fasadnya dengan susunan geometri lengkung dan susunan garis vertikal horizontal. Pintu menggunakan model dua daun pntu serta pola bangunan yang asimetris.

\section{Omahku omahmu resto}

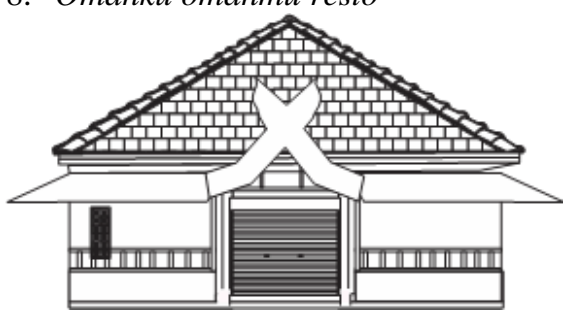

Gambar 11. Fasad bangunan Omahku omahmu resto
Bangunan ini terletak di Jalan Prawirotaman no. 33 Kelurahan Brontokusuman, Kecamatan Mergangsan, Kota Yogyakarta. Bangunan Indis ini saat ini berfingsi sebagai resto yang sudah di renovas dengan atap limasan titik, pintu rolling door, terdapat ornamen garis lengkung membentuk tanda silang, dengan peninggian lantai $30 \mathrm{~cm}$ dari permukaan tanah sehingga memerlukan tangga untuk akses ke bangunan dengan pola bangunan simetris.

\section{Parikesit}

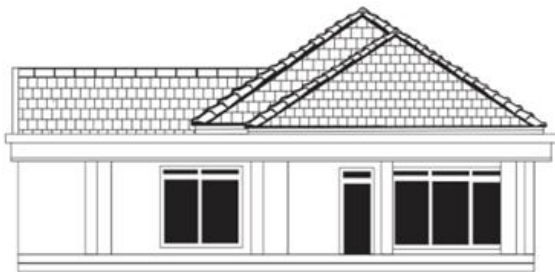

Gambar 12. Fasad bangunan Parikesit

Bangunan ini terletak di Jalan Prawirotaman no. 32 Kelurahan Brontokusuman, Kecamatan Mergangsan, Kota Yogyakarta. Bangunan Indis ini menggunakan atap limasan dengan penambahan atap kecil di bagian depan bangunan, menggunakan pintu dengan satu daun pintu dan pola asimetris pada bangunan.

\section{Garden guest house}

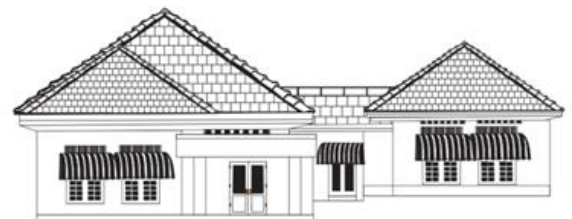

Gambar 13. Fasad bangunan Garden guest house

Bangunan ini terletak di Jalan Prawirotaman no. 26 Kelurahan Brontokusuman, Kecamatan Mergangsan, Kota Yogyakarta. Bangunan Indis ini menggunakan atap limasan dengan penambahan atap kecil di bagian depan bangunan, menggunakan pintu dengan dua daun pintu dan pola simetris pada bangunan.

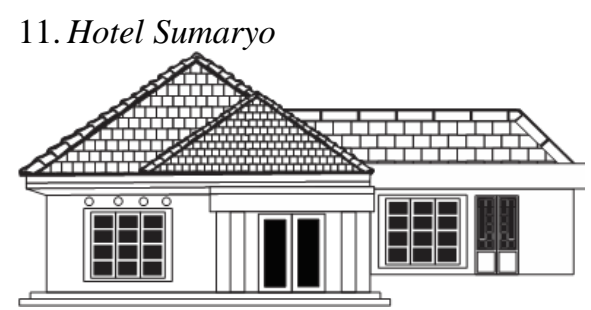

Gambar 14. Fasad bangunan Hotel Sumaryo 
Bangunan ini terletak di Jalan Prawirotaman no. 22 Kelurahan Brontokusuman, Kecamatan Mergangsan, Kota Yogyakarta. Bangunan Indis ini menggunakan atap limasan dengan penambahan atap kecil di bagian depan bangunan, menggunakan pintu dengan dua daun pintu dan pola asimetris pada bangunan.

\section{Arkadia communal space}

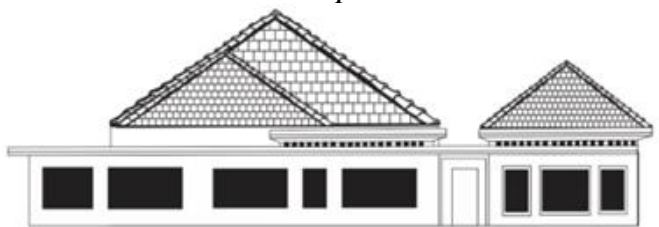

Gambar 15. Fasad bangunan Arkadia communal space

Bangunan ini terletak di Jalan Prawirotaman no. 15 Kelurahan Brontokusuman, Kecamatan Mergangsan, Kota Yogyakarta. Bangunan Indis ini sempat menjadi bangunan tua yang tidak terurus karena ditinggalkan pemiliknya, namun sekarang bangunan ini menjadi communal space dengan gaya Indisnya yang masih dipertahankan. Bangunan ini menggunakan atap limasan dengan penambahan atap kecil di bagian depan bangunan dan pola asimetris pada bangunan.

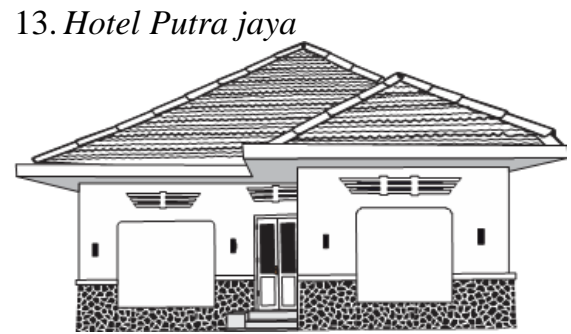

Gambar 16. Fasad bangunan hotel Putra jaya

Bangunan ini terletak di Jalan Prawirotaman no. 10 Kelurahan Brontokusuman, Kecamatan Mergangsan, Kota Yogyakarta. Bangunan Indis ini menggunakan atap limasan dengan penambahan atap kecil di bagian depan bangunan, menggunakan pintu dengan dua daun pintu dan pola simetris pada bangunan.

\section{Wisma Gajdah}

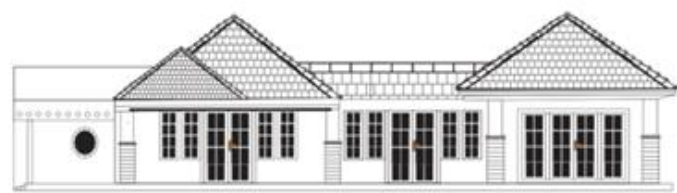

Gambar 17. Fasad bangunan wisma Gajah
Bangunan ini terletak di Jalan Prawirotaman no. 6 Kelurahan Brontokusuman, Kecamatan Mergangsan, Kota Yogyakarta. Bangunan Indis ini menggunakan atap limasan dengan penambahan atap kecil di bagian depan bangunan, menggunakan pintu dengan dua daun pintu dan pola asimetris pada bangunan.

Dari uraian di atas ada beberapa tipe pada tiap elemen fasad bangunan Indis di kawasan Jalan Prawirotaman. Berikut akan dibahas tipe-tipe dan ditemukan tipe yang paling dominan sebagai karakteristik fasad bangunan Indis di Jalan Prawirotaman.

\section{Karakteristik atap}

Terdapat variasi atap pada bangunan Indis yang ada di kawasan Jalan Prawirotaman, yaitu: atap limasan titik, atap limasan garis, atap limasan dengan tambagan atap kecil akibat penambahan ruang depan) dan atap pelana. Semua bangunan Indis yang ada di kawasan Jalan Prawirotaman menggunakan genting tanah liat sebagai material penutup atapnya. Pada seluruh bagian atap bangunan Indis di kawasan Jalan Prawirotaman tidak ada satupun hiasan atau ornamen di bagaian atapnya.

Beikut tipe atap bangunan Indis yang ada di kawasan Jalan Prawirotaman:

a. Tipe-A: Atap limasan titik, menggunakan genteng tanah liat;

b. Tipe-B: Atap limasan garis dengan posisi membujur atau melintang searah dengan bentuk site, menggunakan genteng tanah liat;

c. Tipe-C: Atap limasan dengan tambahan atap kecil (akibat penambahan ruang depan), menggunakan genteng tanah liat;

d. Tipe-D: Atap pelana, menggunakan genteng tanah liat.

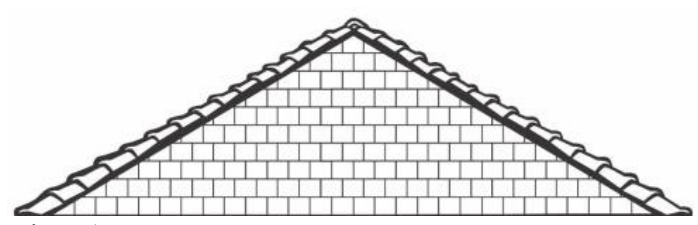

Tipe-A

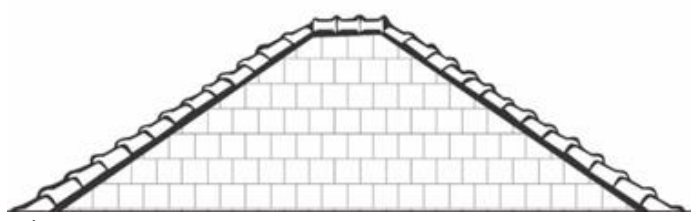

Tipe-B 


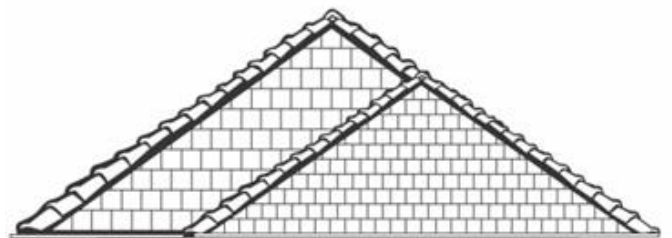

Tipe-C

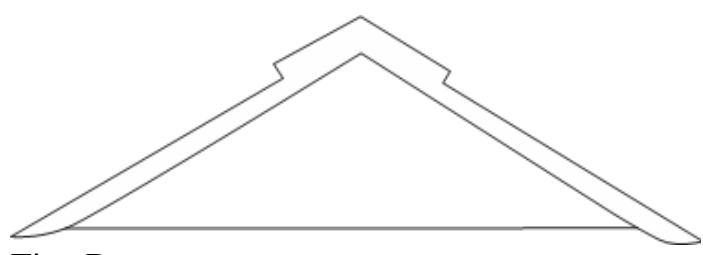

Tipe-D

Gambar 18. Tipe atap bangunan Indis di kawasan Jalan Prawirotaman

Tabel 1. Elemen fasad berdasarkan bentuk atap

\begin{tabular}{cccc}
\hline Variabel & $\begin{array}{c}\text { Nomor } \\
\text { Unit }\end{array}$ & $\begin{array}{c}\text { Jumlah } \\
\text { Unit }\end{array}$ & Persentase \\
\hline Tipe-A & 4,8 & 2 & $14 \%$ \\
Tipe-B & 7 & 1 & $8 \%$ \\
Tipe-C & $1,3,6$, & 9 & $64 \%$ \\
& 9,10, & & \\
& 11,12, & & \\
Tipe-D & 13,14 & 2,5 & $14 \%$ \\
\hline
\end{tabular}

Berdasarkan analisis bentuk atap pada Tabel 1 , yang paling dominan adalah Tipe- $\mathrm{C}$ dengan total 9-unit bangunan dan persentase $64 \%$ yaitu atap limasan dengan tambahan atap kecil (akibat penambahan ruang depan) dengan genteng tanah liat. Dominan kedua adalah Tipe-A dan Tipe-D dengan total 4-unit bangunan dan persentase 14\% yaitu atap limasan garis dengan posisi membujur atau melintang searah dengan bentuk site, menggunakan genteng tanah liat dan atap pelana, menggunakan genteng tanah liat.

\section{Dinding}

Dinding merupakan bagian paling luar dari bangunan yang memiliki nilai estetika yang berpengaruh terhadap kenyamanan visual (Karisztia, Pangarsa, and Antariksa 2008; Harani and Motic 2017). Dinding pada bangunan Indis memiliki proporsi dimana lebar dinding lebih besar dibandingkan dengan tingginya. Elemen pemberi nilai estetika yang melekat pada dinding adalah material, warna dan kolom. Bangunan Indis yang ada di kawasan Jalan Prawirotaman dominan menggunakan dinding beton berwarna cerah seperti cream atau putih yang memberi kesan monumental yang merupakan salah satu ciri dasar bangunan Indis. Terdapat beberapa kategori warna dan material pada dinding bangunan Indis di kawasan Jalan Prawirotaman yang akan dijabarkan dengan bebrbagai tipe sebagai berikut: a. Tipe-A: Dinding beton, dominan warna putih.

b. Tipe-B: Dinding beton, dominan warna kuning.

c. Tipe-C: Dinding beton, dominan warna cream.

d. Tipe-D: Dindingbeton kombinasi batu alam, dominan warna hijau.

e. Tipe-F: Dinding beton kombinasi batu alam, dominan warna hijau.

f. Tipe-G: Dinding beton kombinasi batu alam, dominan warna hijau.

g. Tipe-H: Dinding beton kombinasi batu alam, dominan warna coklat.
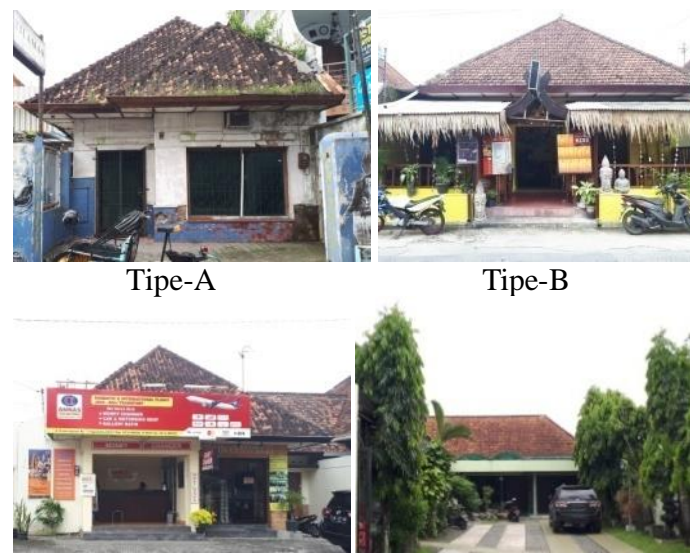

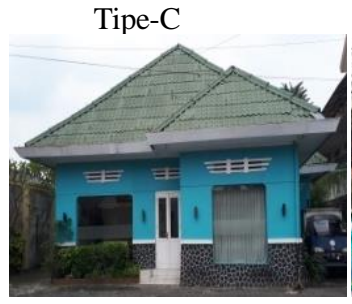

Tipe-E

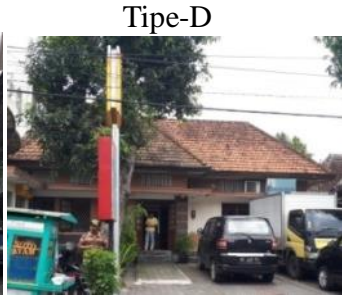

Tipe-F
Gambar 19. Tipe warna bangunan Indis di kawasan Jalan Prawirotaman

Tabel 2. Elemen fasad berdasarkan dinding

\begin{tabular}{cccc}
\hline Variabel & $\begin{array}{c}\text { Nomor } \\
\text { Unit }\end{array}$ & $\begin{array}{c}\text { Jumlah } \\
\text { Unit }\end{array}$ & Persentase \\
\hline Tipe-A & $2,5,6$ & 3 & $21 \%$ \\
Tipe-B & 7,8 & 2 & $14 \%$ \\
Tipe-C & $3,9,10$, & 5 & $35 \%$ \\
& 12,14 & & \\
Tipe-D & 11 & 1 & $8 \%$ \\
Tipe-E & 13 & 1 & $8 \%$ \\
Tipe-F & 1,4 & 2 & $14 \%$ \\
\hline
\end{tabular}


Berdasarkan analisis tipe dinding pada tabel2, dapat disimpulkan bahwa tipe dinding yang paling dominan adalah Tipe-C dengan total 5-unit bangunan dengan persentase $35 \%$ yaitu dinding beton, dominan warna cream. Dominan kedua adalah Tipe-A dengan total 3-unit bangunan dengan persentase $21 \%$ yaitu dinding beton dominan warna putih.

\section{Bukaan bangunan}

Bukaan pada bangunan yang akan dibahas pada penelitian ini yaitu pintu, jendela. Terdapat variasi jenis pintu dan jendela yang akan di bahas dalam penelitian ini serta seperti yang telah disebutkan terdapat unsur dekoratif pada bagian ventilasi di beberapa bangunan dengan pola yang unik yang membuat tampilan fasad menjadi menarik

\section{Pintu}

Merupakan salah satu elemen yang penting dalam sebuah fasad bangunan (Tri Widyanti, Antariksa, dan Yunita Titisari 2009; Harani dan Motic 2017; Santoso 2017; Ramli 2018). Pintu pada bangunan Indis di kawasan jalan Prawirotaman memiliki beberapa tipe menurut bentuk dan materialnya, ada 7 kategori pintu yang ada pada bangunan Indis di Kampung Prawirotaman ditunjukkan pada gambar 20 sebagai berikut:

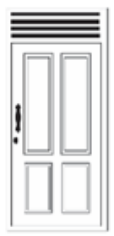

Tipe-1A

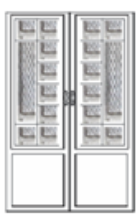

Tipe-2C

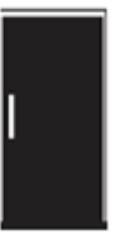

Tipe-1B

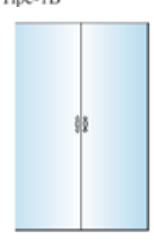

Tipe-2D

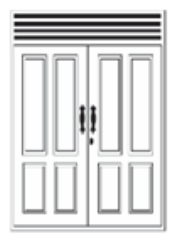

Tipe-2A

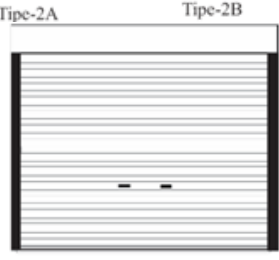

Tipe-E

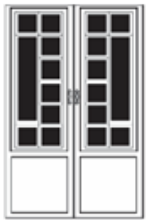

Gambar 20. Tipe pintu bangunan Indis di kawasan Jalan Prawirotaman

a. Tipe-1A: 1 daun pintu, material kayu;

b. Tipe-1B: 1 daun pintu, material kaca;

c. Tipe-2A: 2 daun pintu, material kayu;

d. Tipe-2B: 2 daun pintu, material kayu kombinasi kaca ray-ban; e. Tipe-2C: 2 daun pintu, material kayu kombinasi kaca;

f. Tipe-2D: 2 daun pintu, material kaca tempered

g. Tipe-E: baru/modern, tipe pintu rolling door

h. Tipe-F: tidak ada pintu

Tabel 3. Elemen fasad berdasarkan pintu

\begin{tabular}{cccc}
\hline Variabel & $\begin{array}{c}\text { Nomer } \\
\text { Unit }\end{array}$ & $\begin{array}{c}\text { Jumlah } \\
\text { Unit }\end{array}$ & Presentase \\
\hline Tipe-1A & 2,9 & 2 & $14 \%$ \\
Tipe-1B & 5 & 1 & $8 \%$ \\
Tipe-2A & 4,6 & 2 & $14 \%$ \\
Tipe-2B & 3,13, & 4 & $28 \%$ \\
& 14,10 & & $8 \%$ \\
Tipe-2C & 1 & 1 & $8 \%$ \\
Tipe-2D & 7 & 1 & $8 \%$ \\
Tipe-E & 3 & 1 & $21 \%$ \\
Tipe-F & $8,11,12$ & 3 &
\end{tabular}

Berdasarkan hasil analisis tipe pintu pada tabel 3, dapat disimpulkan bahwa bentuk pintu yang paling dominanyaitu tipe-2B total 4-unit bangunan dan persentase $28 \%$ yaitu 2 daun pintu dengan menggunakan material kayu kombinasi kaca ray-ban dan tidak ada pintu. Selain itu ada tipe-F jumlah 3-unit bangunan dengan persentase $21 \%$ yaitu tidak ada pintu.

Jendela

Bangunan Indis yang ada di kawasan Jalan Prawiotaman memiliki lima tipe jendela. Jendelajendela yang ada pada fasad bangunan mrmiliki ukuran yang besar dan tinggi sejajar dengan pintu. Warna yang digunakan pada material jendela senada dengan warna material pintunya.

Berikut tipe jendela yang ada di kawasan Jalan Prawirotaman:

a. Tipe-A: Jendela panjang terpisah

b. Tipe-B: Jendela kaca massif

c. Tipe-C: Jendela panjang menerus

d. Tipe-D: Jendela kotak terpisah

e. Tipe-E: Tidak ada jendela
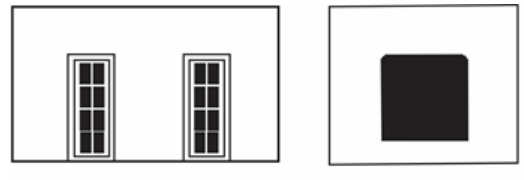

Tipe-A

Tipe-B
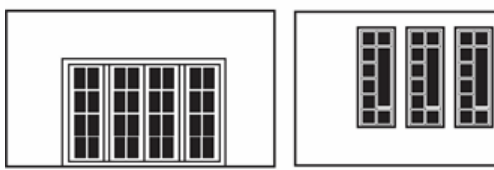

TipeTipe-D

Gambar 21. Tipe jendela bangunan Indis di kawasan Jalan Prawirotaman 
Tabel 4. Elemen fasad berdasarkan jendela

\begin{tabular}{cccc}
\hline Variabel & $\begin{array}{c}\text { Nomor } \\
\text { Unit }\end{array}$ & $\begin{array}{c}\text { Jumlah } \\
\text { Unit }\end{array}$ & Presentase \\
\hline Tipe-A & 14 & 1 & $8 \%$ \\
Tipe-B & $2,3,4$, & 8 & $57 \%$ \\
& $5,6,7$, & & \\
& 12,13 & & \\
Tipe-C & 9 & 1 & $8 \%$ \\
Tipe-D & $3,1,10$ & 3 & $21 \%$ \\
Tipe-E & 8,11 & 2 & $14 \%$ \\
\hline
\end{tabular}

Dari analisis 5 tipe jendela pada tabel 4 dapat disimpulkan bahwa tipe jendela yang paling dominan pada bangunan Indis di Kampung Prawirotaman adalah tipe-B dengan total 8-unit bangunan dan persentase $57 \%$ yaitu jendela dengan kaca massif, namun diperkirakan jendela dengan kaca massif ini merupakan jendela yang telah diubah oleh pemiliknya saat bangunan Indis di Kampung Prawirotaman mengalami perubahan fungsi menjadi rumah industri batik. Sehingga bisa dilihat tipe jendela dominan lainnya yaitu tipe-D dengan jenis jendela kotak terpisah. Mungkin sekali bahwa tipe jendela tersebut merupakan tipe jendela yang dominan menjadi pembentuk fasad bangunan Indis di kampung Prawirotaman sebelum dilakukan perubahan oleh pemiliknya.

Lantai

Hal yang unik yang dapat dilihat dari lantai bangunan Indis yang ada di kawasan Jaan Prawirotaman adalah terdapat peninggian lantai dari tanah.

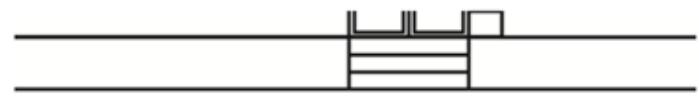

Gambar 22. Peninggian lantai bangunan Indis di kawasan Jalan Prawirotaman

Pondasi yang dibuat lebih tinggi dari tanah sehingga terlihat dari luar. Sehingga dominan bangunan Indis di kawasan Jalan prawirotaman memiliki pijakan seperti tangga untuk masuk ke dalam bangunan sekitar 20-60 cm dari permukaan tanah sehingga ada beberapa yang menggunakan tangga untuk akses masuk bangunan. Ada pula bangunan yang memiliki lebih dari satu lantai.

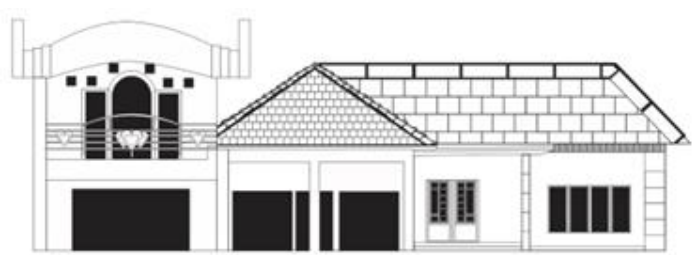

Gambar 23. Bangunan hotel Prayogo III, menunjukkan bahwa bangunan Indis lebih dari satu lantai

Selain untuk memberikan kesan megah pada bangunan, peninggian ini berguna untuk menghindari kelembaban dari tanah sehingga lantai dan dinding tetap kering dan tidak berlumut (Soekiman 1997).

Pola

Sebagian besar pola fasad keseluruhan bangunan Indis yang ada di kawasan Jalan Prawirotaman memiliki pola yang simetris pada bangunan utamanya, jika dilihat secara keseluruhan bangunan menjadi asimetris karena adanya renovasi penambahan ruang seiring dengan perkembangan jaman, komposisi pada setiap bagian bangunan yang saling berdekatan memberikan kesan yang seimbang pada bangunan tersebut. Pola bangunan Indis yang ada di kawasan Jalan Prawirotaman ini memang memiliki perbedaan dengan bangunan Indis yang cenderung simetris. Bangunan-bangunan Indis yang ada di kawasan Jalan Prawirotaman sudah memiliki variasi pola bangunannya yang seimbang.

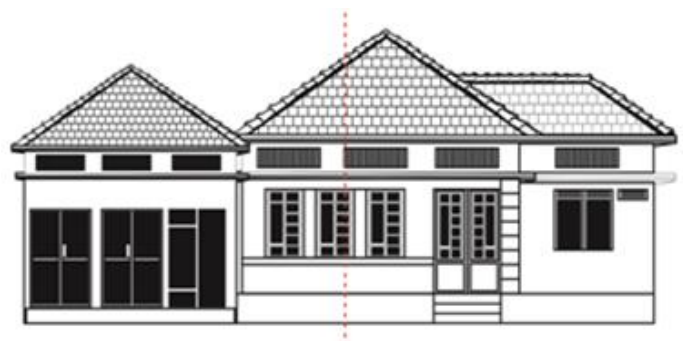

Gambar 24. Pola bangunan asimetris

\section{Ornamen}

Ornamen yang terdapat di bangunan Indis di kawasan Jalan Prawirotaman berbentuk unsur garis vertikal dan horizontal. Selain garis vertikal dan horizontal, ada beberapa bangunan Indis di kawasan Jalan Prawirotaman yang memiliki bentuk ventilasi unik, sehingga dapat menjadi elemen dekoratif pada fasad bangunannya. Ada yang berbentuk lingkaran, ada yang berbentuk 
persegi dan berbentuk geometri dengan unsur garis tegas dan material beton yang selaras dengan kusen dan atapnya.
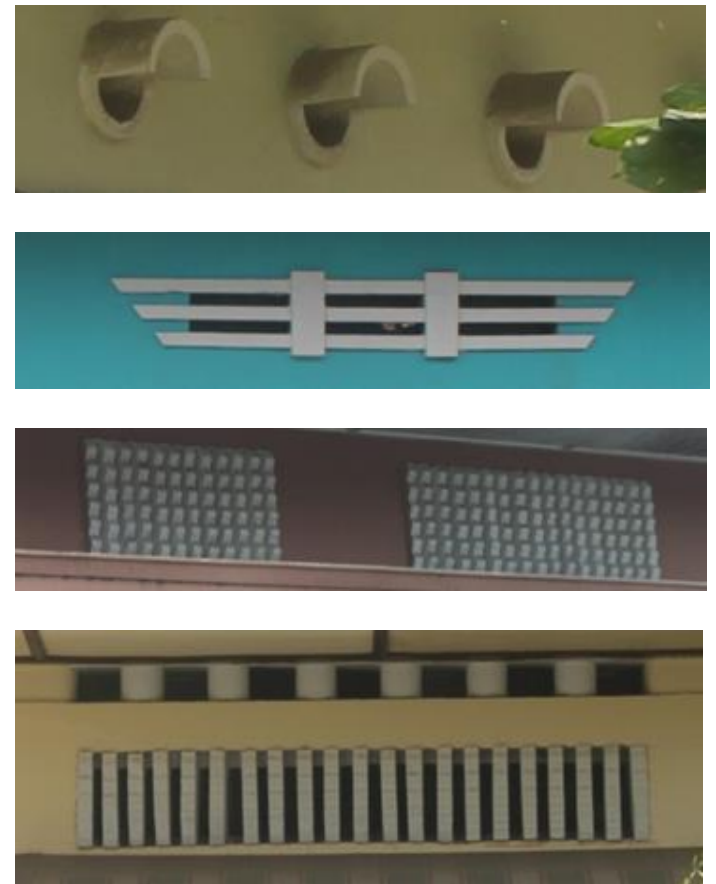

Gambar 25. Tipe ornamen pada bangunan Indis di kawasan Jalan Prawirotaman

Penelitian ini menunjukan bahwa terdapat beberapa karakteristik bangunan Indis yang ada di kawasan Jalan Prawirotaman dilihat dari elemen fasad bangunannya. Menurut Ching (1991) fasad merupakan bagian muka bangunan yang menghadap kearah jalan yang dibedakan dengan desainnya (Ching 1991). Pada fasad bangunan Indis yang ada di Prawirotaman diambil 7 variabel penting pembentuk fasad seperti atap, dinding, pintu, dan jendela, lantai, pola dan ornamen. Pada setiap variabel yang diteliti memiliki karakteristiknya masing-masing. Pada atap terdapat 4 tipe berdasarkan bentuk dan meterialnya, pada elemen dinding terdapat 6 tipe berdasarkan warna dan materialnya, pada pintu terdapat 7 tipe, sedangkan pada jendela terdapat 4 tipe jendela. Variabel pola dan ornamen bangunan juga diteliti sebagai pendukung karakteristik fasad bangunan Indis yang ada di kawasan Jalan Prawirotaman.

Pengamatan atas elemen fasad bangunan Indis yang ada di kawasan Jalan Prawirotaman menunjukan bahwa ada beberapa tipe bentuk pada elemen fasadnya dan diambil yang paling dominan. Atap yang paling dominan pada bangunan Indis di Kampung Prawirotaman adalah atap limasan dengan tambahan atap kecil (akibat penambahan ruang depan) menggunakan genteng tanah liat, dinding dominan berwarna cream dengan material beton, pintu yang dominan adalah pintu kayu kombinasi kaca ray-ban dengan 2 daun pntu, jendela massif, dengan peninggian lantai dan pola fasad yang asimetris. Berdasarkan teori Karsten dalam Sumalyo (1993) dan Wibisono (2014) karakteristik bangunan Indis secara umum yaitu atap berbentuk limasan, dinding beton menggunakan warna pastel seperti cream, pada bidang vertikal fasad depan bangunan menggunakan aksentuasi garis linier sehingga secara visual memperpendek ketinggian bidang fasad bangunan dengan dibantu material batu alam/permukaan finishing kasar sebagai penutup dinding bagian bawah, dan pada bagian pintu dan jendela memiliki komposisi simetris dengan pintu ganda sedangkan material menggunakan kombinasi kayu dan kaca. Dalam hal ini dapat disimpulkan adanya perbedaan karakteristik pada variabel dari teori karakteristik dasar bangunan Indis.

Salah satu elemen yang yang berbeda adalah jendela dan pola bangunan, menurut Yuliandi (2016) seiring dengan perkembangan jaman fungsi jendela dan pola bangunan semakin bertambah dengan adanya nilai keindahan, keamanan, kekuatan dan juga ekonomi. Sehingga diperkirakan jendela dan pola bangunan dirubah oleh pemilik bangunan pada saat terjadi perubahan fungsi bangunan menjadi rumah industri batik, dimana bagian depan bangunan digunakan sebagai ruang display batik dan dipenambahan ruang (Nofiawaty and Yuliandi 2016).

\section{Kesimpulan}

Kesimpulan dari penelitian ini dapat ditemukan karakteristik fasad bangunan Indis di kawasan Jalan Prawirotaman. Karakteristik ditentukan oleh elemen-elemen pembentuk fasad seperti atap, dinding, bukaan bangunan (pintu dan jendela), lantai dan pola bangunan yang paling dominan. Karakteristiknya akan dijabarkan sebagai berikut: (a) Atap bangunan Indis yang ada di kawasan jalan Prawirotaman dominan menggunakan atap limasan dengan tambahan atap kecil (akibat penambahan ruang depan) dengan genteng tanah liat; (b) Dinding menggunakan 
material beton dengan warna cream atau putih; (c) Pintu menggunakan 2 daun pintu dengan menggunakan material kayu kombinasi kaca rayban; (d) Jendela dengan kaca massif; $€$ Peninggian lantai antara 20-60 cm (memerlukan tangga untuk akses masuk ke dalam bangunan) dan didominasi dengan bangunan berlantai satu; (f) Pola fasad keseluruhan bangunan Indis yang ada di kawasan jalan Prawirotaman memiliki pola yang asimetis namun terkesan seimbang; (g) Ornamen pada bangunan terdapat pada bagian ventilasi dan kolom dengan unsur garis tegas dan material beton.

\section{Saran}

Penelitian karakteristik arsitektur Indis pada fasad bangunan di kawasan Jalan Prawirotaman Yogyakarta ini diharapkan dapat memberikan pengetahuan kepada masyarakat dan masukan bagi pemerintah dalam pengembangan Jalan Prawirotaman Yogyakarta sehingga budaya dan sejarahnya tetap terjaga.

a. Bagi penelitian selanjutnya

Masih diperlukan penelitian lanjutan untuk bisa memahami karakteristik bangunan Indis di kawasan Jalan Prawirotaman pada sisi lain bagunannya. Penelitian ini adalah penelitian awal dengan 14 bangunan Indis yang ada di kawasan Jalan Prawirotaman. Karena keterbatasanketerbatasan yang ada, penelitian ini hanya membahas bagian fasad bangunannya saja. Oleh karena itu penelitian lanjutan yang lebih mendalam tidak hanya pada fasadnya namun pada elemen arsitekturalnya dengan gambaran yang lebih rinci dan tajam.

Penelitian karakteristik fasad bangunan Indis ini hanya dilakukan pada bangunan-bangunan yang berada di pinggir Jalan Prawirotaman sehingga rentang penelitian ini masih sangat luas, bisa dilanjutkan hingga ke bangunan-bangunan di belakangnya atau menuju Jalan Prawirotaman II. Selain itu masih diperlukan penelitian mengenai keberlanjutan karakter fasad bangunan Indis di kawasan Jalan Prawirotaman.

b. Bagi pihak pemerintah

Langkah yang perlu dilakukan pemerintah adalah memberikan batasan pada pembangunan bangunan baru yang ada di kawasan Jalan Prawirotaman Yogyakarta, agar kawasan tersebut tetap memiliki karakteristik dan tejaga budaya serta sejarahnya. c. Bagi masyarakat

Masyarakat diharapkan dapat terlibat dan mendukung upaya pemerintah dalam menjaga karakter kawasan Jalan Prawirotaman Yogyakarta.

d. Bagi wisatawan

Bagi wisatawan diharapkan turut serta menjaga dan memahami budaya yang ada pada kawasan Kampung Prawirotaman dengan cara tidak merusak, mengotori dan tidak melakukan perbuatan yang melanggar budaya di kawasan Jalan Prawirotaman Yogyakarta.

\section{Referensi}

Arinto, Fransiscus Xaverius Eddy. 2018. 'Pelestarian Arsitektur Berdasarkan Architectural Architypes Melalui Metode Grafis'. ARTEKS : Jurnal Teknik Arsitektur 3 (1): $\quad$ 29-36. https://doi.org/10.30822/artk.v3i1.52.

Askari, Amir Hossein, and Kamariah Binti Dola. 2009. 'Influence of Building Façade Visual Elements on Its Historical Image Influence of Building Façade Visual Elements on Its Historical Image: Case of Kuala Lumpur City, Malaysia'. Journal of Design and Built Environment 5 (1): 49-59. https://ejournal.um.edu.my/index.php/jdbe/ar ticle/view/4971/2813.

Ching, FDK. 1991. 'Arsitektur: Bentuk, Ruang Dan Susunannya'. Erlangga, Jakarta. https://doi.org/10.1177/1087054708326271.

DIY, Dinas Kebudayaan Provinsi. 2014. 'Yogyakarta Masa Kolonial'. 2014. http://www.tasteofjogja.org/contentdetil.php? kat $=$ artk\&id=MzY5\&fle $=$ Y29udGVudC5wa $\mathrm{HA}=\&$ lback=a2F0PWFydGsmYXJ0a2thdD0 xJmxiYWNrPQ==.

Fauziah, Nur, Antariksa Antariksa, and Jenny Ernawati. 2012. 'Kualitas Visual Fasade Bangunan Modern Pasca Kolonial Di Jalan Kayutangan Malang'. RUAS 10 (2): 11-18. https://doi.org/10.21776/ub.ruas.2012.010.02. 2.

Harani, Arnis Rochma, and Ken Motic. 2017. 'Pengaruh Fasade Bangunan Terhadap Karakter Visual Kawasan (Studi Kasus: Pecinan Semarang, Malaysia Dan Singapura)'. Jurnal Pengembangan Kota 5 (1): 1-8. https://doi.org/10.14710/jpk.5.1.1-8. Karisztia, Arthantya Dwi, Galih Widjil Pangarsa, 
and Antariksa. 2008. 'Tipologi Facade Rrumah Tinggal Kolonial Belanda Di Kayutangan - Malang'. Arsitektur E-Journal.

Kristiani, Lusia, and Atyanto Dharoko. 1996. 'Perubahan Tata Ruang Bangunan "rumah Usaha" Di Prawirotaman Yogyakarta'. Universitas Gadjah Mada.

Laksmi Kusuma Wardani, and Leona Triyulianti. 2011. 'PENGARUH BUDAYA INDIS PADA INTERIOR GEREJA PROTESTAN INDONESIA BARAT IMANUEL SEMARANG'. Dimensi Interior.

Mahatmanto. 2015. 'Role of the Journal of Building Engineers in Dutch East India in Discussing the Emergence of Indonesian Modern Architecture'. Journal of Asian Architecture and Building Engineering 14 (3): 529-32. https://doi.org/10.3130/jaabe.14.529.

Makkasahe, $\quad$ Umar $\quad$-. 2018. 'TRADISIONALISME DALAM ARSITEKTUR KOLONIAL BELANDA DI KOTA GORONTALO'. ARTEKS, Jurnal Teknik Arsitektur. https://doi.org/10.30822/artk.v3i1.154.

Muhadjir, Noeng. 1996. Metodologi Penelitian Kualitatif. Yogyakarta: Rake Sarasin.

Nofiawaty, and Beli Yuliandi. 2016. 'Pengaruh Store Atmosphere Terhadap Keputusan Pembelian Konsumen Pada Outlet Nyenyes Palembang'. Jurnal Ilmu Dan Riset Manajemen.

Ramli, Syamsun. 2018. 'Tipologi Dan Morfologi Fasade Rumah Tradisional Kampung Ciptagelar'. Local Wisdom: Jurnal Ilmiah Kajian Kearifan Lokal 10 (2): 75-90. https://doi.org/10.26905/lw.v10i2.2680.
Rapoport, Amos. 1969. House, Form, and Culture. New York: Prentice Hall.

Salura, Purnama. 2013. 'The Confusing Languange of Building Façades Observed along Ciumbuleuit Road in Bandung'. Journal of Language and Literature 4 (2): 101-5. https://doi.org/10.7813/j1l.2013/4-2/14.

Santoso, Imam. 2017. 'PENELUSURAN HISTORIS MELALUI VISUAL BANGUNAN ART DECO SEBUAH UPAYA BUFFER KUALITAS WAJAH KOTA KE ERA KOMERSIALISASI DI MALANG'. Mintakat: Jurnal Arsitektur 18 (1): 31-37. https://doi.org/10.26905/mintakat.v18i1.1396

Soekiman, Djoko. 1997. 'Diskusi Ilmiah Arkeologi VII: Seni Bangunan Gaya Indis, Pemilikan, Pelestarian, Dan Pemanfaatannya'. Yogyakarta.

Sugini, and Sudaryono. 1997. 'Tipomorfologi Perubahan Rumah Pada Perumahan Minomartani Yogyakarta'. Universitas Gadjah Mada.

Sumalyo, Yulianto. 1993. Arsitektur Kolonial Belanda Di Indonesia. Yogyakarta: Gadjah Mada University Press.

Tri Widyanti, Artika, Antariksa, and Ema Yunita Titisari. 2009. 'Pelestarian Stasiun Kereta Api Kota Baru Malang'. Arsitektur E-Journal.

Wibisono, Tony Kunto, and Arya Ronald. 2014. 'Ciri-Ciri Bangunan Rumah Indis Di Kotabaru Yogyakarta'. Gadjah Mada University.

http://etd.repository.ugm.ac.id/penelitian/deta il $/ 74848$. 